\title{
Geomodelling of Destruction of Soils of Ukrainian Steppe Due to Water Erosion
}

\author{
Nataliia Vasylivna Dudiak', Vitalii Ivanovich Pichura1*, \\ Larisa Aleksandrovna Potravka', Natalia Vladimirovna Stratichuk' \\ 1 Kherson State Agricultural University, Ukraine, 73006, Kherson, Stritens'ka str. 23, \\ * Corresponding author's e-mail: pichuravitalii@gmail.com
}

\begin{abstract}
Spatial raster distribution models of the values of factors influencing the potential soil erosion hazard were created using GIS technologies. The erosion hazard was estimated using the modified RUSLE (Revised Universal Soil Loss Equation) model. The potential of annual soil loss of arable land was calculated. The spatial gradation of erosion violation of administrative and territorial units in the steppe zone of Ukraine was provided. About $32.7 \%$ of arable land that is subject to high erosion hazard was allocated. About 48 administrative and territorial units have a specific area less than 5\% of erosion disturbed lands. They are characterized by a resistant type of agrolandscapes regarding the water-erosion processes. Most administrative and territorial units with high erosive-accumulative potential (the percentage of the area is $15 \%$ or more) are located in the western and southwestern parts of the steppe zone of Ukraine. The specific area of erosion hazardous lands reaches up to $32 \%$ in separate administrative-territorial units. The obtained results allow determining the need for a spatially discrete-distribution implementation of adaptive-landscape anti-erosion design with the elements of soil-protective agriculture.
\end{abstract}

Keywords: water erosion, RUSLE, rainfall erosivity, soil erodability, topography factor, erosion index for crops, steppe zone, GIS technologies, geomodelling

\section{INTRODUCTION}

Soil erosion due to water is referred to as the most dangerous degradation processes that causes significant economic damage and deteriorates the environmental condition of the territorial landscape structures. As of January 1, 2017, the area of agricultural land of Ukraine is $42.7 \mathrm{mln}$ ha (70.8\% of the country's land fund), including arable land area that is $32.5 \mathrm{mln}$ ha $(78.4 \%$ of agricultural land). The area of agricultural land that experiences systematic soil destruction due to water erosion is $13.3 \mathrm{mln}$ ha $(31.1 \%$ of agricultural land area), including arable land that is 10.6 ha (32.6\% of arable land). The lands with highly and moderately eroded soils are $4.5 \mathrm{mln}$ ha $(13.8 \%$ of arable land), 68 thousand ha completely lost the humus horizon (Extended five-year report..., 2017). From 300 to 600 million tons of soil is annually lost due to erosion in the territory of the country. Water erosion processes lead to the deterioration of physical properties of soil, reduction and complete destruction of humus horizon, resulting in a significant decrease in the reserves of humus, macro and microelements, deterioration of soil fertility, a decrease in crop yield up to $60 \%$ and increase in the costs of agrotechnological measures (Pichura et al., 2017). In Ukraine, from 310 to $460 \mathrm{~kg} / \mathrm{ha}$ of arable land, $9.0-28.0 \mathrm{~kg} / \mathrm{ha}$ of nitrogen, $21-28 \mathrm{~kg} / \mathrm{ha}$ of phosphorus, $180-370$ $\mathrm{kg} / \mathrm{ha}$ of potassium, on average, are carried away together with products of erosion. The loss of agricultural products due to erosion exceeds 2.7-3.7 $\mathrm{cwt} / \mathrm{ha}$ of grain units. Potential grain yield is reduced by $0.5-2.0 \mathrm{cwt} / \mathrm{h}$ a with every eroded centimeter of humus horizon. Annually, the environmental and economic damage due to erosion is greater than 300 USD per ha of arable land.

The products of soil erosion destruction are redistributed in the direction of surface runoff, 
which leads to a natural anthropogenic increase in the accumulative processes of agrochemicals, nutrients, heavy metals in surface waters. This leads to a significant deterioration of water quality and provokes the eutrophication processes in water bodies, silting of ponds, reservoirs and valleys of small rivers, causing overregulation of runoff and complete disappearance of small rivers (Lisetskii et al., 2014; Pichura et al., 2017, 2018). Optimization of the erosion subsystem of territorial, natural and economic systems for agriculture in the steppe zone of Ukraine represents the need to establish a condition for the functioning of environmentally-balanced, highly productive agricultural landscapes. The basis for optimization of the erosion subsystem of agrolandscapes is the use of geostatistical and mathematical models with elements of remote sensing of the Earth for a spatiotemporal analysis of the interaction of natural and economic factors. These models are the basis for assessment of the water erosion hazard of a territory, the intensity of soil loss, the determination and justification of effective land and water protection measures regarding optimization of the land fund on the grounds of adaptive landscape principles (Lisetskiy et al., 2014, 2015).

\section{MATERIALS AND METHODS}

The modified empirical and statistical model RUSLE (Revised Universal Soil Loss Equation) was used to simulate soil loss due to water-erosion (State Standard 17.4.4.03-86..., 1986; Grushetsky et al., 1990; Renard et al., 1997; Lisetskiy et al., 2015; Pichura, 2016):

$$
A=R \cdot K \cdot L S \cdot C \cdot P
$$

where: A is the average multi-year value of erosion due to rainfall runoff, tons/ha per year;

$\mathrm{R}$ is the average multi-year rainfall erosivity, standard units;

$\mathrm{K}$ is the soil removal due to water (erodability), t/ha per unit of rainfall erosivity; LS is the topography factor;

$\mathrm{C}$ is the erosion index for crops or crop rotation in general;

$\mathrm{P}$ is the factor of soil protective efficiency of anti-erosion measures.

The RUSLE model was used in the environment of the GIS licensed software product ArcGIS 10.1. The raster models (the cell size is
$90 \times 60 \mathrm{~m}$ ) of each integrated factor of the model of soil erosion due to water in the territory of the entire transborder Dnieper river basin were created for this purpose. The spatial model of average annual rainfall erosivity $(R)$ was obtained on the basis of extrapolation of decompositions of the cartogram data of rainfall erosion index (Grushetsky et al., 1990). Vectorization of soil maps of the steppe zone of Ukraine was carried out in the determination of the soil cover erodibility factor or factor of soil resistance to erosion $(K)$. The $K$ parameter was calculated and the spatial raster model was obtained for each soil type, taking into account their granulometric composition according to the classification of soil erodability factors ( $\mathrm{t} / \mathrm{ha}$ per year).

The $L$ and $S$ factors in the RUSLE model reflect the impact of topography on erosion. It is proven (Kouli et al., 2009) that the increase in length and steepness of the slope causes a higher velocity of water flows and development of soil erosion processes is increased, respectively. The specific effects of topography on soil erosion are estimated by the dimensionless factor LS as the product of components of the length of slope $(L)$ and the steepness of slope $(S)$. The topography erosivity $(L S)$ was assessed using a spatial analysis of a hydrologically correct digital model of topography (DMT) with the cell size of $30 \times 30 \mathrm{~m}$. In ArcGIS 10.1, the morphometric characteristics of topography are determined and the raster cartograms of the length $(L)$ and slopes $(S)$ of surface are constructed using the "Hydrology tools of Spatial Analyst Tools and Surface of the Spatial Analyst Tools" working module and the $L S$ values were calculated afterwards using the "Raster Calculator" module for each pixel according to the formula (State Standard 17.4.4.03-86..., 1986):

$$
L S=L^{0.5} \cdot\left(0.0011 \cdot S^{2}+0.0078 \cdot S+0.0111\right)
$$

The erosion index for crop or vegetation cover ratio $(C)$ is the effect of growing of crops, agricultural management methods and the impact of land covered with natural vegetation (trees, grass) on reduction of the soil loss in the non-agricultural situation. The soil loss decreases together with increase of vegetation. The vegetation cover ratio $(C)$ is the most sensitive to soil loss together with the factor $L S$ (Benkobi et al., 1994; Biesemans et al., 2000). The data from remote sensing of the Earth (RSE) of a properly calibrated satellite image MODIS with a geometric resolution (spatial resolution) of $\sim 230 \times 230 \mathrm{~m}$ as of June 26,2015 
was used to determine the $C$ factor. The $C$ factor values were generated on the basis of the dimensionless NDVI index (the normalized difference vegetation index). The following formula (Van Leeuwen et al., 2004) was used:

$$
C=\exp (-\alpha((N D V I) /(\beta-N D V I)))
$$

where: $\alpha$ and $\beta$ are dimensionless parameters that determine the shape of the curve referring to the NDVI and $C$ factor. The $\alpha$ and $\beta$ parameters have the values of 2 and 1 , respectively.

The factor of soil protective measures $(P)$ was taken as 1 , assuming that no additional measures were taken.

\section{RESULTS AND DISCUSSION}

Geomodelling of water erosion processes in the Dnipro river basin was carried out on the basis of 4 factors: $R, K, L S$ and $C$.

The $\mathbf{R}$ factor is the average multi-year rainfall erosivity. The assessment of the climatic conditionality of potential soil loss was carried out using factor of energy and rainfall intensity that are reflected in the erosion hazard using relative indices or rainfall erosion index (REI). They are determined by statistical processing of the pluviograms of all runoff producing rainfalls with a layer of precipitation $\geq 10 \mathrm{~mm}$ (erosion hazardous rains). Their main parameters are the total kinetic energy of rain and its maximum intensity over a 30-minute continuous period of time. The rainfall erosivity (Fig. 1a) gradually increases from the south to northwest in the territory of the steppe regions of Ukraine and varies from 5.4 to 8.8.

The $\mathrm{K}$ factor is removal of soil by water (erodability). The soil type and condition index, i.e. the factor of soil resistance to erosion processes, is defined as the ratio of the average annual soil removal due to water from $1 \mathrm{~m}^{2}$ of runoff space to $R$ value depending on the steepness of slope and the percentage content of soil fractions, organic substances of its structure and water permeability. The potential annual loss of fertile topsoil, depending on the rainfall erosivity in the territory of steppe of Ukraine, decreases from the northeast to south from 3.6 to $1.2 \mathrm{t} / \mathrm{ha}$ (Fig. 1b). The agricultural lands in the southern coasts of the Black and Azov Seas are least resistant to erosion processes.
The $\mathbf{C}$ factor is the erosion index for crop or crop rotation in general. This index is largely intended for determining the impact of agricultural crop (crop rotation or vegetation cover) on the erosion processes in agricultural lands. Determination of this factor is quite a difficult task due to large variety of crops and natural vegetation, but scientists (Van Leeuwen et al., 2004) proved the high efficiency of using the data of remote sensing of the Earth, which is based on the NDVI index, for determination of the $C$ factor. The raster model of spatial distribution of the erosion index for crop in the territory of the steppe region that is under research (Fig. 1c) was obtained as a result of deciphering a properly calibrated satellite image MODIS. The $C$ values range from 0 to 1.4. in the direction from the north to south of the steppe zone of Ukraine.

The LS factor is the topography factor. The topography function $L S$ reflects the combined impact of the length and steepness of slopes on erosion hazard for topography. The average values of the topography function $L S$ (GOST 17.4.4.03-86), which vary from 0.2 to 15.0 and more (Fig. 1d) for the agricultural land of the steppe research region, were calculated for the obtained raster of $L S$ values. The average $L S$ values range from 0.2 to 1.8 according to separate administrative and territorial units. The agricultural lands of the northwestern part of the steppe zone of Ukraine, most of which are located in the Odessa region, are subject to the greatest erosion hazard for the topography.

According to the classification of Svitlychnyi (1995) and Buryak (2015), the territories that have the value of soil removal due to water lower than $2 \mathrm{t} / \mathrm{ha}$ per year are deemed erosion-safe lands. If more than 2 tha per year are removed, the lands are erosion hazardous and require antierosion measures in accordance with the category of erosion hazard. As a result of GIS modelling using the modified RUSLE model the erosion hazard assessment was performed, the potential of annual soil losses of arable land was calculated (Fig. 2) and the spatial gradation of erosion disturbance of agricultural land of the administrative and territorial units of the steppe region that is under research was performed. The distribution of agricultural land according to the gradation of the erosion hazard is shown in Table 1.

The deemed erosion safe lands are confined to the plains and buffer boundaries of the watershed parts of slopes and constitute $67.3 \%$ of the total 

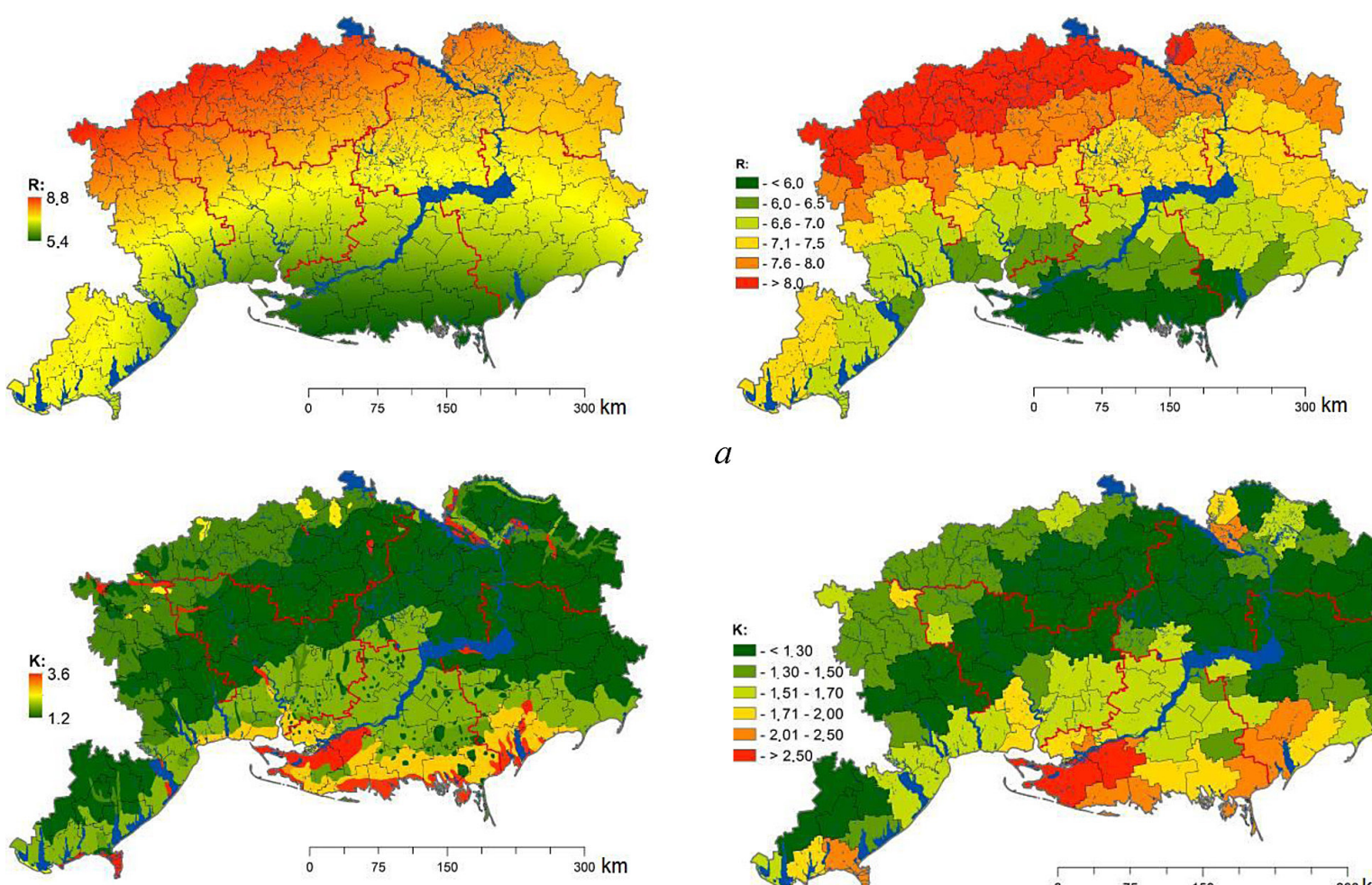

$a$
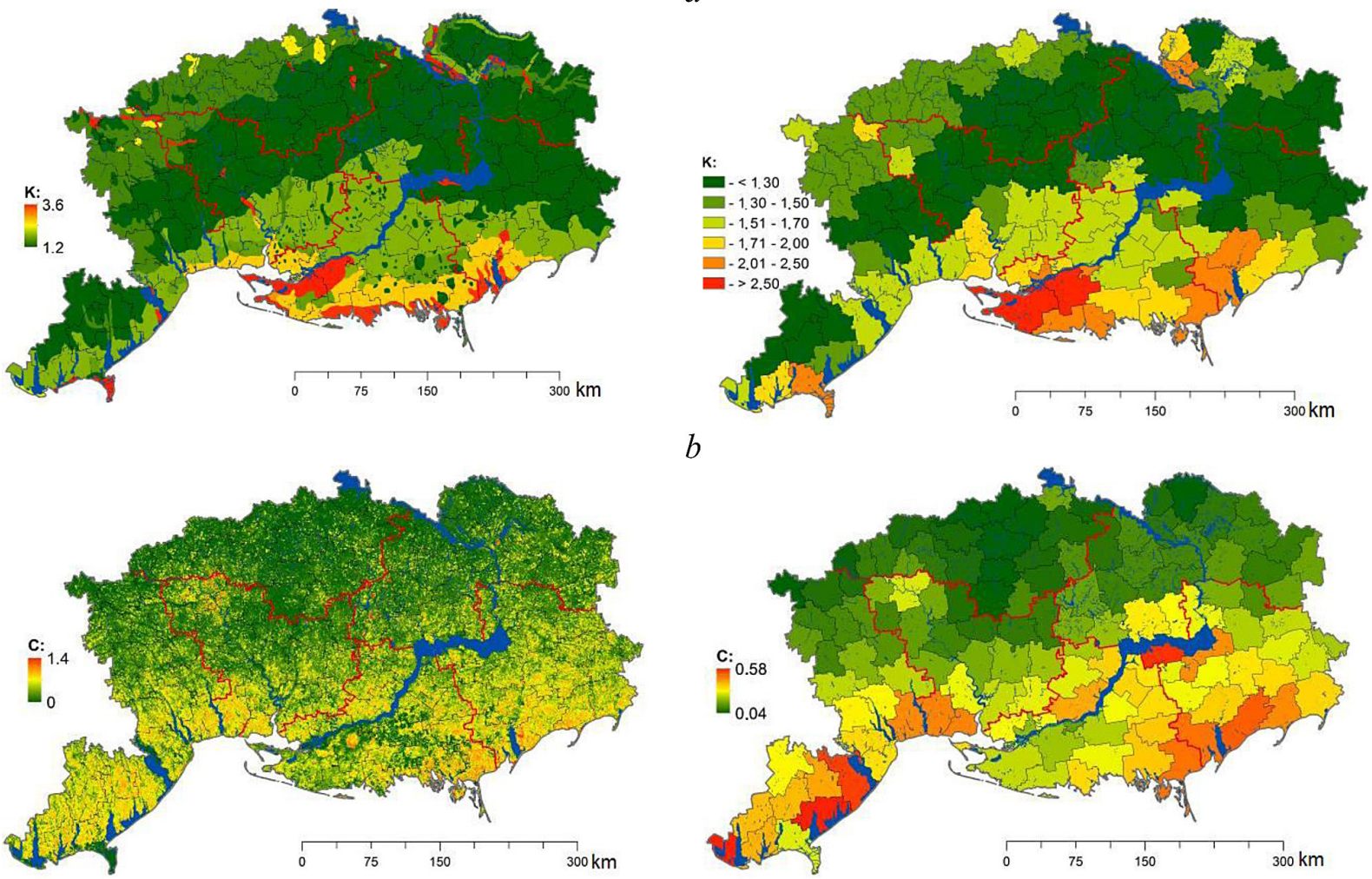

$b$

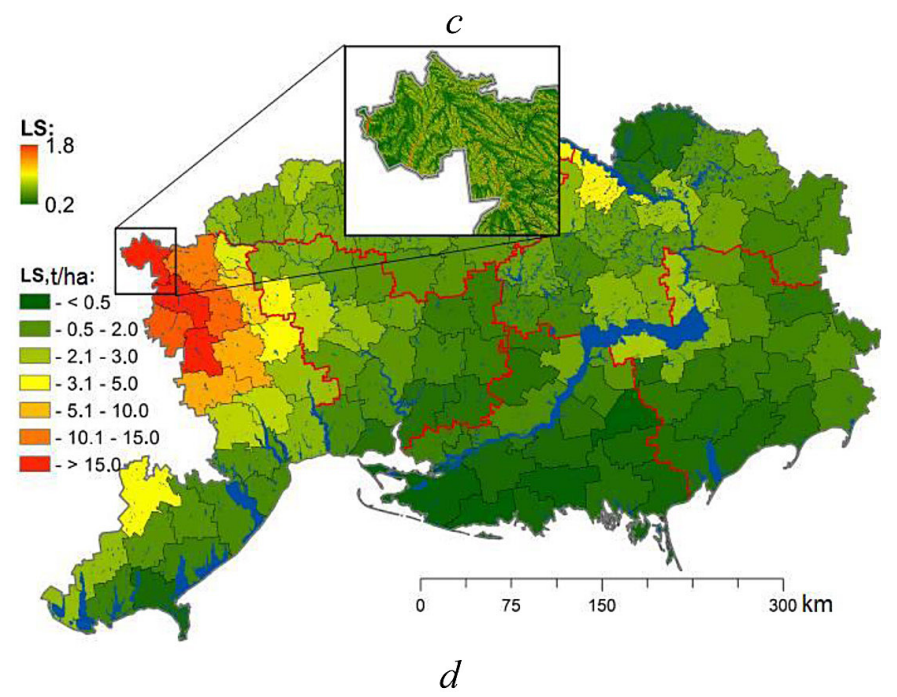

Figure 1. Distribution of values of factors of hazard of soil erosion processes due to water in the steppe regions of Ukraine: $\mathrm{a}$ - the rainfall erosion index $(\mathrm{R}) ; \mathrm{b}$ - the soil resistance (erodibility) to erosion, $\mathrm{t} / \mathrm{ha}(\mathrm{K})$; $\mathrm{c}-$ the erosion index for crop or crop rotation in general (C); $\mathrm{d}$ - the topography factor (LS) 
Table 1. Distribution of arable land according to the potential soil erosion hazard under the rainfall effect

\begin{tabular}{|c|c|c|c|}
\hline Erosion hazard & Soil removal due to water, $\mathrm{t} / \mathrm{ha}$ per year & The area, thous. ha & Specific weight, $\%$ \\
\hline Deemed absent & $<0.5$ & 8857.5 & 67.30 \\
\hline Minimum & $0.5-2.0$ & 2880.5 & 21.89 \\
\hline Little & $2.1-5.0$ & 1039.3 & 7.90 \\
\hline Average & $5.1-10.0$ & 284.3 & 2.16 \\
\hline High & $10.1-20.0$ & 81.4 & 0.62 \\
\hline Very high & $>20.0$ & 18.9 & 0.14 \\
\hline \multicolumn{2}{|r|}{ Total } & 13162 & 100 \\
\hline
\end{tabular}
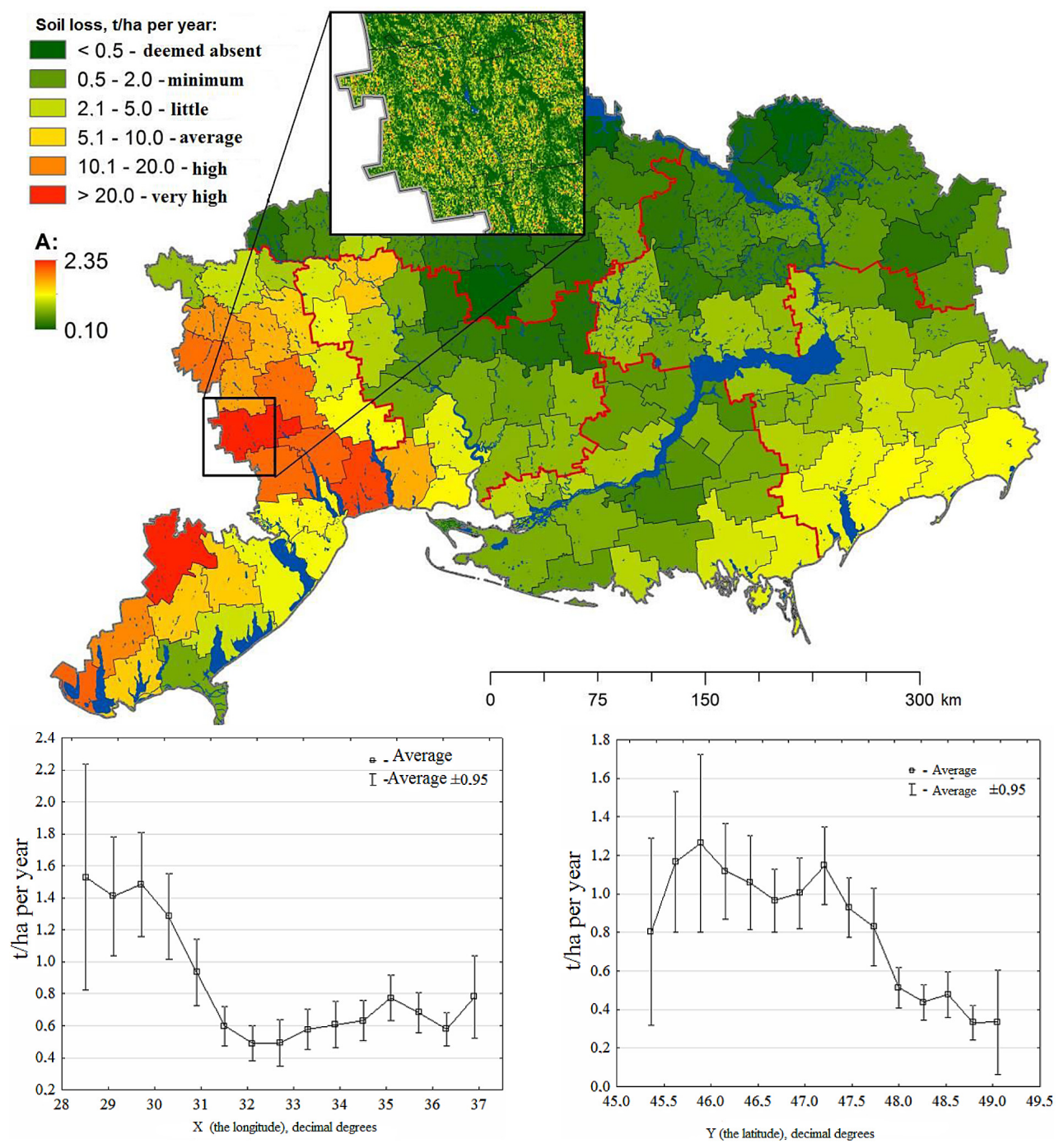

$b$

$$
c
$$

Spatial distribution function of soil loss values:

$$
S L_{w e}=-2.21 \mathrm{X}+0.041 \mathrm{X}^{2}+17.70 Y-0.184 Y^{2}-0.013 X Y-376.34 \quad r^{2}=0.48
$$

where $\mathrm{X}$ is the longitude, decimal degrees, $\mathrm{Y}$ is the latitude, decimal degrees

Figure 2. Spatial distribution of total soil losses ( $\mathrm{t} /$ ha per year) due to wind erosion in the steppe zone of Ukraine: $a$-the spatial distribution cartogram; $b$-the heterogeneity of distribution from the west to east; $c$-the heterogeneity of distribution from the south to north; $d$-the spatial distribution model

arable land area. According to the results of spatial modelling, about 4304.5 thousand ha of erosion hazardous lands were allocated $(32.7 \%$ of the total arable land area). About 48 administrative and territorial units, located mostly in the northern part of the steppe region that is under research, have the specific area lesser than $5 \%$ of erosion disturbed lands and soil losses more than $2.0 \mathrm{t} / \mathrm{ha}$ per 


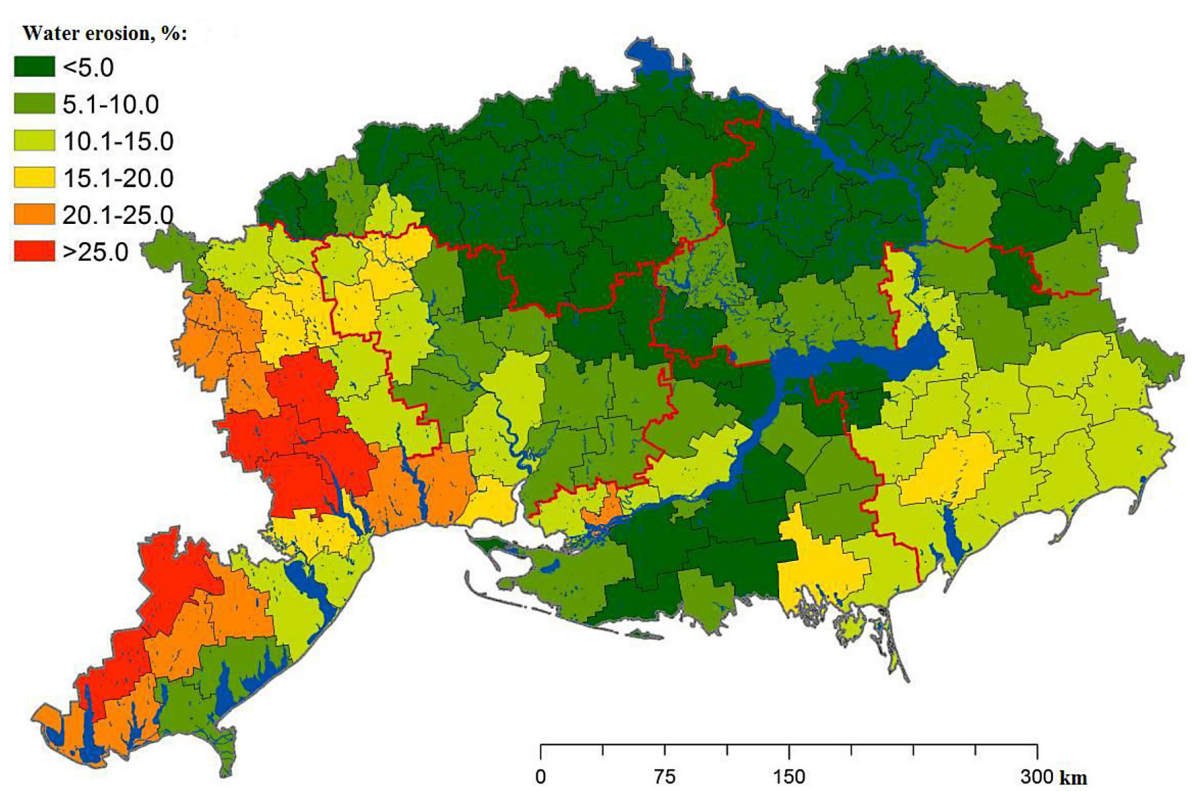

Figure 3. The percentage of the territory of certain regions of the Southern Ukraine that is subject to soil erosion hazard due to water (more than 2.0 t/ha per year) in relation to the area of arable land

year (Fig. 3). They are characterized by a resistant type of agricultural landscapes regarding the water erosion processes.

Most administrative and territorial units with high erosive-accumulative potential (the percentage of the area is $15 \%$ or more) are located in the western and southwestern parts of the Ukrainian steppe zone. The specific area of erosion hazardous lands reaches up to $32 \%$ in separate administrative-territorial units. It is useful to prioritize the implementation of adaptive-landscape antierosion design with elements of soil-protective agriculture in these territories.

It is necessary to provide primarily the following system of measures in order to form environmentally resistant agro-landscapes and reduce the erosion-accumulative processes in the territory of the Ukrainian steppe zone: melioration organizational and economic measures: creating a system of soil-protective crop rotations, a mosaic pattern of land, conservation of degraded lands, etc.; hydromelioration measures: implementing balanced irrigation, anti-erosion ponds, water protection zones, etc.; agromelioration measures: restricting the use of heavy tilling machines, crating a buffer strip of perennial vegetation, implementing soil protection technologies, reducing pesticide application, processing the cross slopes, etc.; forest melioration measures: creating forest strips that protect fields and regulate runoff, ravine forest strips; conducting continuous afforestation of slopes.

\section{CONCLUSIONS}

The spatial gradation of the potential of soil erosion disturbance in the steppe zone of Ukraine was carried out using GIS and RSE technologies and the modified empirical statistical model RUSLE. About 4304.5 thousand ha of arable land with increased (more than $2 \mathrm{t} /$ ha per year) erosion hazard $(32.7 \%$ of the total arable land area) was allocated. The deemed erosion-safe lands were confined to the plain and buffer boundaries of the watershed parts of slopes and constitute $67.3 \%$ of the total arable land area, but they are also subject to water erosion processes. About 48 administrative and territorial units, located mostly in the northern part of the steppe region that is under research, have the specific area less than 5\% of erosion disturbed lands. They are characterized by a resistant type of agricultural landscapes regarding the water erosion processes. Most administrative and territorial units with high erosive-accumulative potential (the percentage of the area is $15 \%$ or more) are located in the western and southwestern parts of the Ukrainian steppe zone. The specific area of erosion hazardous lands reaches up to $32 \%$ in separate administrative-territorial units. The obtained results enable to determine the necessity of implementing spatially discrete-distribution of adaptive-landscape anti-erosion design with the elements of soil-protective agriculture. 


\section{REFERENCES}

1. Benkobi L., Trlica M.J. and Smith J.L. 1994. Evaluation of a refined surface cover subfactor for use in RUSLE. Range Manage. (47), 74-78.

2. Biesemans J., Meirvenne M.V. and Gabriels D. 2000. Extending the RUSLE with the Monte Carlo error propagation technique to predict long-term average off-site sediment accumulation. Soil Water Conserv, (55), 35-42.

3. Buryak Zh. A. 2015. Basin organization of nature management in Belgorod ecoregion. Cand. Geogr. Sciences. Moscow, pp. 193 (in Russian).

4. Extended five-year report on desertification and degradation of land. Kyiv, 2017, pp. 45 (in Russian).

5. Grushetsky A.V., Krivov V.N., Panochko N.M., Telesh P.V., Chepkov B.M. and Moskalenko V.M. 1990. Album of typical solutions of marking linear boundaries in the development of intrafarm land management projects with the contour-reclamation area organization. UkrNIIzemproekt, 97 (in Russian).

6. Kouli M., Soupios P. and Vallianatos F. 2009. Soil erosion prediction using the Revised Universal Soil Loss Equation (RUSLE) in a GIS framework, Chania, Northwestern Crete, Greece. Environ Geol, 57(3), 483-497.

7. Lisetskii F.N., Pavlyuk Ya.V., Kirilenko Zh.A. and Pichura V.I. 2014. Basin organization of nature management for solving hydroecological problems. Russian Meteorology and Hydrology, 39(8), 550-557.

8. Lisetskiy F.N., Degtyar A.V., Buryak Zh.A. et al. 2015. Rivers and water bodies of Belogorya. In: F.N. Lisetskiy (Ed.). All-Russian public organization Russian Geographical Society. NRU Belgorod State University. Belgorod: Konstanta, 362 (in Russian).

9. Lisetskiy F.N., Zemlyakova A.V., Narozhnyaya A.G., Terekhin E.A., Pichura V.I., Buryak Zh.A., Samofalova O.M. and Grigoryeva O.I. 2014. Geoplanning of rural areas: experience of the implementation of the concept of river basin environmental management at the regional level. Bulletin of ONU. Series: Geographical and Geological Sciences, 19, 3(22), 125-137 (in Russian).

10. Pichura V., Pilipenko Y., Domaratsky E. and Gadzalo A. 2017. Environmental assessment of the state of trans-boundary watersheds of the Dnieper. Agroecological Journal, 2, 102-116.

11. Pichura V.I. 2016. Spatial prediction of soil erosion risk in the Dnieper river basin using revised universal soil loss equation and GIS-technology. Bulletin of Zhytomyr National Agroecological University, 2(56), 3-11.

12. Pichura V.I., Domaratsky Y.A., Yaremko Yu.I., Volochnyuk Y.G. and Rybak V.V. 2017. Strategic Ecological Assessment of the State of the Transboundary Catchment Basin of the Dnieper River Under Extensive Agricultural Load. Indian Journal of Ecology, 44 (3), 442-450.

13. Pichura V.I., Malchykova D.S., Ukrainskij P.A., Shakhman I.A. and Bystriantseva A.N. 2018. Anthropogenic Transformation of Hydrological Regime of The Dnieper River. Indian Journal of Ecology, 45(3), 445-453.

14. Renard K.G., Foster G.R., Weesies G.A., McCool D.K. and Yoder D.C. 1997. Predicting soil erosion by water: a guide to conservation planning with the Revised Universal Soil Loss Equation (RUSLE). Agriculture Handbook, 703, USDA-ARS.

15. State Standard 17.4.4.03-86. 1986. Method for determining potential hazards of erosion caused by rain. Moscow, 12 (in Russian).

16. Svitlychnyi O.O. 1995. Quantitative evaluation of the features of the force erosion process and the issue of the optimization of using lands in danger of erosion. Geographic Sciences, Odessa State University, 47 (in Russian).

17. Van Leeuwen W.J.D. and Sammons G. 2004. Vegetation dynamics and soil erosion modelling using remotely sensed data (MODIS) and GIS. Tenth Biennial USDA Forest Service Remote Sensing Applications Conference, 5-9 April 2004, UT. US Department of Agriculture Forest Service Remote Sensing Applications Center, Salt Lake City. 